\title{
Cyclic somatic embryogenesis and efficient plant regeneration from callus of safflower
}

\author{
J. VIJAYA KUMAR ${ }^{1}$, B.D. RANJITHA KUMARI ${ }^{1} *$ and E. CASTAÑO ${ }^{2}$ \\ Department of Plant Science, Bharathidasan University, Tiruchirappalli-620 024, Tamil Nadu, India ${ }^{1}$ \\ CICY, UBMMP, Merida, Yucatan CP 97200, Mexico $^{2}$
}

\begin{abstract}
Efficient plant regeneration through somatic embryogenesis was established for safflower (Carthamus tinctorius L.) cv. NARI-6. Embryogenic calli were induced from 10 to 17-d-old cotyledon and leaf explants from in vitro seedlings. High frequency (94.3\%) embryogenic callus was obtained from cotyledon explants cultured on Murashige and Skoog's germination (MSG) basal medium supplemented with thidiazuron, 2-isopentenyladenine and indole-3-butyric acid. Primary, secondary and cyclic somatic embryos were formed from embryogenic calli in a different media free of plant growth regulators, however, $100 \%$ cyclic somatic embryogenesis was obtained from cotyledon derived embryogenic calli cultured on MSG. Somatic embryos matured and germinated in quarter-strength MSG medium supplemented with gibberellic acid. Cotyledons with root poles or non root poles were converted to normal plantlets and produced adventitious roots in rooting medium. Rooted plants were acclimatized and successfully transferred to the field.
\end{abstract}

Additional key words: Asteraceae, medicinal plant, plant growth regulators, secondary somatic embryogenesis.

\section{Introduction}

In vitro clonal propagation has the potential for fast multiplication of superior genotypes, allowing the exploitation of maximum genetic gain in the breeding programs. When compared to other methods of in vitro propagation, somatic embryogenesis offers several advantages (Jain 1999), cryopreservation, selection of clones that have been genetically modified, as well as propagation of elite plants (Aitken-Christie 2001). Indirect somatic embryogenesis is a multistep regeneration process starting with the formation of proembryogenic cell masses, followed by somatic embryo formation, maturation, desiccation and plant regeneration (Von Arnold and Eriksson 1981).

The cells forming the embryo are characterized by dense cytoplasmic contents, large starch grains, and a relatively large nucleus with a darkly stained nucleolus. Each pro-embryonic cell is capable of passing through the sequential stages of embryo formation. Two critical events are involved in the early programming of this process: 1) the induction of cytodifferentiation of the proembryonic cells, and 2) the unfolding of the

developmental sequences by these pro-embryonic cells (Kohlenbach 1978).

Safflower (C. tinctorius L.) is an annual oil seed medicinal plant belonging to the family Asteraceae, which is well adapted to semi-arid conditions in the tropics and sub-tropics. Somatic embryogenesis in safflower has been firstly described only with the need of hormone requirements (Mandal et al. 1995). Explant age, carbon source and ethylene effect on direct somatic embryogenesis of safflower were later described by Mandal et al. (2001). The histology of direct somatic embryogenesis was later described by Mandal and Dutta Gupta (2002). Low cytokinin with high auxin concentrations efficiently induced direct somatic embryos in safflower (Mandal and Dutta Gupta 2003). The above mentioned papers were not focused on further development of somatic embryos, their germination and conversion into plantlets. Therefore, our aim has been to define a protocol for cyclic somatic embryogenesis of safflower, as well as to characterize the conversion of the somatic embryos into fully acclimatized field plants.

Received 25 September 2006, accepted 2 June 2007.

Abbreviations: $\mathrm{B}_{5}$ - Gamborg medium; CDEC - cotyledon derived embryogenic calli; 2,4-D - 2,4-dichlorophenoxyacetic acid; $\mathrm{GA}_{3}$ - gibberellic acid; IBA - indole-3-butyric acid; 2-ip - 2-isopentenyladenine; KN - kinetin; LDEC - leaf derived embryogenic calli; MSG medium - Murashige and Skoog's germination medium; NAA - naphthalene-acetic acid; PCD - programmed cell death; PEM - proembryogenic mass; SH - Schenk and Hildebrandt; SE - somatic embryogenesis; TDZ - thidiazuron (1-phenyl-3-(1,2,3thidiazol-5-yl)-urea.

* Corresponding author, fax: (+91) 431240 7045, e-mail: ranjithakumari2004@yahoo.co.in 


\section{Materials and methods}

Plants and callus initiation: Seeds of safflower (Carthamus tinctorius L.) cv. NARI-6 collected at the Nimbhkar Agricultural Research Institute, Maharashtra, India were used for establishing embryogenic cultures. Seeds were immersed in $1.0 \%$ Teepol solution for $2 \mathrm{~min}$, and then were kept under tap water for $20 \mathrm{~min}$. Seeds were further sterilized with $70 \%$ ethanol for $1 \mathrm{~min}$ and rinsed twice with sterile distilled water for $2 \mathrm{~min}$. Then, the seeds were again sterilized with $0.1 \%$ mercuric chloride for $2 \mathrm{~min}$. The surface sterilized seeds were rinsed three times with sterile distilled water, and were aseptically germinated in Murashique and Skoog's germination (MSG) medium (Becwar et al. 1988). Cultures were initially incubated in darkness for $12 \mathrm{~h}$ at $23-25^{\circ} \mathrm{C}$ and then at $25-26^{\circ} \mathrm{C}$ and 12 -h photoperiod.

Cotyledon and leaf explants excised carefully from 10 to 17 -d-old in vitro seedlings were cut transversely into 0.5 to $1.0 \mathrm{~cm}$ long pieces and slight incision was made on the surface of explants. They were abaxial side down cultured on MSG media supplemented with different combinations and concentrations of plant growth regulators (PGR) [thidiazuron (TDZ; $\left.3.5 \mathrm{mg} \mathrm{dm}^{-3}\right)+2$-isopentenyladenine (2-ip; $\left.1.5 \mathrm{mg} \mathrm{dm}^{-3}\right)$, TDZ $\left(5.0 \mathrm{mg} \mathrm{dm}^{-3}\right)$ +2 ,4-dichlorophenoxyacetic acid (2,4-D; $\left.1.0 \mathrm{mg} \mathrm{dm}^{-3}\right)$, TDZ (7.0 $\left.\mathrm{mg} \mathrm{dm}^{-3}\right)+$ indole-3-butyric acid (IBA; $\left.2.0 \mathrm{mg} \mathrm{dm}^{-3}\right)$, TDZ $\left(6.0 \mathrm{mg} \mathrm{dm}^{-3}\right)+2-\mathrm{ip}\left(1.5 \mathrm{mg} \mathrm{dm}^{-3}\right)+$ IBA $\left(2.5 \mathrm{mg} \mathrm{dm}^{-3}\right)$ or TDZ $\left(6.0 \mathrm{mg} \mathrm{dm}^{-3}\right)+2$-ip $\left.\left(1.5 \mathrm{mg} \mathrm{dm}^{-3}\right)+2,4-\mathrm{D}\left(2.0 \mathrm{mg} \mathrm{dm}^{-3}\right)\right], 3.0 \%$ sucrose and $8.0 \mathrm{~g} \mathrm{dm}^{-3}$ agar. The $\mathrm{pH}$ of the culture media was adjusted to 5.7 using $0.1 \mathrm{M} \mathrm{NaOH}$ and $0.1 \mathrm{M} \mathrm{HCl}$, before autoclaving at $121{ }^{\circ} \mathrm{C}$ for $20 \mathrm{~min}$. The cultures were maintained at $25 \pm 2{ }^{\circ} \mathrm{C}$ and 10 to 12 -h photoperiod with irradiation of $30 \mu \mathrm{mol} \mathrm{m} \mathrm{m}^{-2} \mathrm{~s}^{-1}$ (white fluorescent tubes). There were 10 replicates, and the experiment was repeated 4 times. The callus was initiated from the cut end of explant after 2 weeks of culture. The culture conditions remained the same for all experiments unless otherwise specified (Table 1).

Isolation and proliferation of embryogenic calli: Proembryogenic callus was isolated from non-embryogenic callus clumps and subcultured every two weeks thereafter. In each subculture, 5 pro-embryogenic cell clumps were cultured (approximately $0.5 \mathrm{~cm}^{3}$ each clumps) per $250 \mathrm{~cm}^{3}$ conical flask (Borosil, Mumbai, India) containing fresh MSG medium and maintained under the above mentioned conditions. After second subculture, embryogenic callus appeared with different colour and shape. The percentage and fresh mass of embryogenic callus was recorded after $70 \mathrm{~d}$ of culture (Table 1).

Induction of primary somatic embryos: Cotyledon and leaf derived embryogenic calli (CDEC, LDEC; $50 \mathrm{mg}$ ) were isolated from various culture conditions tested, and were subcultured in PGRs free half-strength $\mathrm{B}_{5}$ (Gamborg et al. 1968), SH (Schenk and Hildebrandt 1972) and MSG (Becwar et al. 1988) basal medium containing myoinositol $\left(400 \mathrm{mg} \mathrm{dm}^{-3}\right)$, casamino acid $\left(200 \mathrm{mg} \mathrm{dm}^{-3}\right)$, L-glutamine (500 $\left.\mathrm{mg} \mathrm{dm}^{-3}\right)$, thiamine $\mathrm{HCl}\left(250 \mathrm{mg} \mathrm{dm}^{-3}\right)$, pyridoxine $\mathrm{HCl}\left(250 \mathrm{mg} \mathrm{dm}^{-3}\right)$, nicotinic acid $\left(300 \mathrm{mg} \mathrm{dm}^{-3}\right)$ and L-asparagine $\left(50 \mathrm{mg} \mathrm{dm}^{-3}\right), 7.0 \mathrm{~g} \mathrm{dm}^{-3}$ agar and $1.5 \%$ sucrose for the induction, proliferation and maturation of somatic embryos. The early globular, heart, torpedo and early cotyledonary stage embryos developed on the surface of the calli after 2 weeks of culture. All the cultures were subcultured at every week and maintained at day/night temperature of $25 / 16^{\circ} \mathrm{C}$ and 12-h photoperiod. The mature bipolar early cotyledonary stage embryos were developed directly from the torpedo stage embryos, and were maintained on same medium with the same culture conditions for further development. Total number of primary somatic embryos and percentage of response was recorded at the end of $30 \mathrm{~d}$ of culture (Table 2).

Secondary and cyclic somatic embryogenesis: Primary somatic embryos at different stages (globular, heart, torpedo and cotyledon) cultured on the above mentioned media could be converted into proembryogenic mass (PEM) in which secondary somatic embryos were formed. The cultures were incubated at $25 \pm 2{ }^{\circ} \mathrm{C}$ in the same medium for further proliferation of secondary somatic embryos. The embryo culture was routinely subcultured and maintained onto the same medium which also produced cyclic embryos. There were 10 replicates per treatment and the experiment was repeated 6 times. After $60 \mathrm{~d}$ of culture, the percentage of secondary embryogenesis and total number of embryos was recorded. The cyclic production of embryos was also recorded after $90 \mathrm{~d}$ of culture (Table 2).

Germination and plant regeneration: For germination, mature cotyledon stage embryos were cultured in darkness in semi solid quarter-strength MSG with $1.5 \%$ sucrose, $250 \mathrm{mg} \mathrm{dm}^{-3}$ glutamine, $100 \mathrm{mg} \mathrm{dm}^{-3}$ arginine, $10 \mathrm{mg} \mathrm{dm}^{-3}$ proline and different concentrations of gibberellic acid $\mathrm{GA}_{3}\left(0.1,0.3,0.5,0.7\right.$ and $\left.0.9 \mathrm{mg} \mathrm{dm}^{-3}\right)$. There were 6 flasks per experiment and the experiment was repeated 4 times. Germination frequency was recorded after 2, 4 and 6 weeks. For plant conversion, the mature cotyledonary stage embryos were grown under $16-\mathrm{h}$ photoperiod with irradiance of $30 \mu \mathrm{mol} \mathrm{m} \mathrm{m}^{-2} \mathrm{~s}^{-1}$ in filter paper bridges containing $1.0 \%$ sucrose. Plant conversion rate was recorded after $10 \mathrm{~d}$ of culture (Table 3 ). Well-germinated mature cotyledon stage embryos with root poles and non-root poles were transferred into rooting medium [quarter-strength MSG basal salts supplemented with naphthalene-acetic acid (NAA; $2.0 \mathrm{mg} \mathrm{dm}^{-3}$ ) + benzyladenine (BA; $0.1 \mathrm{mg} \mathrm{dm}^{-3}$ ) or NAA $\left(1.5 \mathrm{mg} \mathrm{dm}^{-3}\right)+\operatorname{kinetin}\left(\mathrm{KN} ; 0.3 \mathrm{mg} \mathrm{\textrm {dm } ^ { - 3 }}\right)$, and putrescine $\left.\left(0.5-3.0 \mathrm{mg} \mathrm{dm}^{-3}\right)\right]$. After $1 \mathrm{month}$, the 
rooting results were recorded (Table 4). The experiment was repeated 4 times. The plantlets with adventitious roots were carefully washed with tap water to remove medium, and then transferred to plastic pots containing sand, garden soil and Vermiculite (1:2:1). Potted plants were incubated at $25{ }^{\circ} \mathrm{C}$ for $10 \mathrm{~d}$ under irradiance of $30 \mu \mathrm{mol} \mathrm{m} \mathrm{m}^{-2} \mathrm{~s}^{-1}$. After emergence of new leaves, the acclimated plants were transplanted into greenhouse.

\section{Results}

Embryogenic calli initiation and proliferation: The adaxial surface of the cotyledon and leaf explants induced primary callus after $14 \mathrm{~d}$ of culture in MSG basal medium with $3.0 \%$ sucrose. Differences were obtained depending on the various concentrations of PGRs tested (Table 1). The analysis of variance showed that the type of explants and hormone used (auxin or cytokinins) significantly affected the percentage of callusing. In this case, TDZ and 2-ip alone or in combinations with IBA in the medium induced yellow-creamy pro-embryogenic callus from the cotyledon and light-creamy pro-embryogenic callus (PEC) in leaf explants. However, in TDZ and 2,4-D supplemented media, cotyledon explants produced light yellow friable callus whereas white friable calli were obtained in leaf explants. Moreover, addition of TDZ, 2-ip and 2,4-D produced light-creamy yellow PEC from cotyledonary and light-creamy white in leaf explants. Among the media strengths, full-strength MSG supplemented with $6.0 \mathrm{mg} \mathrm{dm}^{-3} \mathrm{TDZ}+1.5 \mathrm{mg} \mathrm{dm}^{-3} 2$-ip
$+2.5 \mathrm{mg} \mathrm{dm}^{-3}$ IBA produced highest fresh mass $(655 \mathrm{mg})$ with $94.3 \%$ of embryogenic callus in cotyledons after $70 \mathrm{~d}$ of culture (Table 1, Fig. 1A). Occasionally few globular like structure were found from the embryogenic callus (data not shown). All the selected PEC showed stable growth for at least 3 - 4 months.

Primary somatic embryogenesis in PGRs free culture: White and yellow creamy PEC from various culture conditions were shifted to PGRs-free media (for detail see Materials and methods) in which embryogenic cells were proliferated and changed their morphological nature to light golden yellow embryogenic cells within $14 \mathrm{~d}$. The embryogenic cells produced numerous embryos (globular, heart, torpedo and cotyledon) within 2 - 3 weeks of culture in all the three media tested (Fig. $1 B, C, D$ ). In this case, we noticed higher frequency $(72.5 \%)$ of primary somatic embryos from cotyledon (CDEC) than from leaf derived embryogenic calli (LDEC; $63 \%$ ) in half-strength

Table 1. Effect of growth regulators on embryogenic callus induction from cotyledon and leaf explants of safflower. Data were scored after $70 \mathrm{~d}$ of culture. Means of 80 explants \pm SE. Means with the same letters are not statistically significant at $P<0.05$.

\begin{tabular}{|c|c|c|c|c|c|c|c|}
\hline $\begin{array}{l}\text { TDZ } \\
{\left[\mathrm{mg} \mathrm{dm}^{-3}\right]}\end{array}$ & $\begin{array}{l}\text { 2-ip } \\
{\left[\mathrm{mg} \mathrm{dm}^{-3}\right]}\end{array}$ & $\begin{array}{l}\text { 2,4-D } \\
{\left[\mathrm{mg} \mathrm{dm}^{-3}\right]}\end{array}$ & $\begin{array}{l}\text { IBA } \\
{\left[\mathrm{mg} \mathrm{dm}^{-3}\right]}\end{array}$ & $\begin{array}{l}\text { Cotyledon } \\
\text { embryogenic callus } \\
{[\%]}\end{array}$ & $\begin{array}{l}\text { callus fresh mass } \\
{[\mathrm{mg}]}\end{array}$ & $\begin{array}{l}\text { Leaf } \\
\text { embryogenic callus } \\
{[\%]}\end{array}$ & $\begin{array}{l}\text { callus fresh mass } \\
{[\mathrm{mg}]}\end{array}$ \\
\hline 3.5 & 1.5 & 0 & 0 & $532 \pm 3.6 b$ & $83.7 \pm 0.8 \mathrm{ab}$ & $428 \pm 4.7 b$ & $72.5 \pm 0.4 b$ \\
\hline 5.0 & 0 & 1.0 & 0 & $149 \pm 5.9 \mathrm{e}$ & $40.1 \pm 0.7 \mathrm{c}$ & $102 \pm 1.2 \mathrm{e}$ & $36.2 \pm 0.9 \mathrm{~d}$ \\
\hline 7.0 & 0 & 0 & 2.0 & $340 \pm 3.3 c$ & $61.2 \pm 0.4 b$ & $283 \pm 4.1 c$ & $58.3 \pm 0.5 c$ \\
\hline 5.5 & 1.5 & 2.0 & 0 & $252 \pm 2.7 d$ & $52.0 \pm 0.8 b c$ & $188 \pm 8.4 \mathrm{~d}$ & $46.2 \pm 0.7 \mathrm{~cd}$ \\
\hline 6.0 & 1.5 & 0 & 2.5 & $655 \pm 3.5 \mathrm{a}$ & $94.3 \pm 0.7 \mathrm{a}$ & $590 \pm 2.9 a$ & $78.5 \pm 0.8 \mathrm{a}$ \\
\hline
\end{tabular}

Table 2. Effect of different half-strength media devoid of growth regulators on primary, secondary and cyclic somatic embryogenesis from cotyledon (CDEC) or leaf (LDEC) explants of safflower. The frequency of embryo-forming explants and the mean number of embryos per explant were scored. Means of 120 embryogenic calli \pm SE. Means followed by the same letter within the column are not statistically significant at $P<0.05$.

\begin{tabular}{|c|c|c|c|c|c|c|c|}
\hline Medium & Explant & $\begin{array}{l}\text { Primary SE [after } 3 \\
\text { embryogenesis } \\
{[\%]}\end{array}$ & $\begin{array}{l}30 \mathrm{~d}] \\
\text { number of } \\
\text { embryos }\left[\text { callus }^{-1} \text { ] }\right.\end{array}$ & $\begin{array}{l}\text { Secondary SE [ } \\
\text { embryogenesis } \\
{[\%]}\end{array}$ & $\begin{array}{l}\text { fter } 60 \mathrm{~d}] \\
\text { number of } \\
\text { embryos }\left[\text { callus }^{-1}\right]\end{array}$ & $\begin{array}{l}\text { Cyclic SE [after } \\
\text { embryogenesis } \\
{[\%]}\end{array}$ & $\begin{array}{l}0 \mathrm{~d}] \\
\text { number of } \\
\text { embryos }\left[\text { callus }^{-1} \text { ] }\right.\end{array}$ \\
\hline $\mathrm{B}_{5}$ & $\mathrm{CDEC}$ & $33.0 \pm 1.1 \mathrm{~cd}$ & $19.1 \pm 1.2 b c$ & $46.0 \pm 1.7 \mathrm{~cd}$ & $28.0 \pm 1.5 b c$ & $69.6 \pm 3.4 b c$ & $57.0 \pm 2.8 b c$ \\
\hline MSG & CDEC & $72.5 \pm 1.6 \mathrm{a}$ & $48.5 \pm 3.6 \mathrm{a}$ & $85.0 \pm 3.2 \mathrm{a}$ & $61.0 \pm 5.4 \mathrm{a}$ & $100.0 \pm 2.6 \mathrm{a}$ & $152.0 \pm 3.9 \mathrm{a}$ \\
\hline $\mathrm{SH}$ & $\mathrm{CDEC}$ & $40.4 \pm 0.7 \mathrm{c}$ & $25.7 \pm 4.9 b$ & $57.6 \pm 3.0 \mathrm{c}$ & $33.0 \pm 2.5 b$ & $77.2 \pm 0.7 \mathrm{ab}$ & $91.5 \pm 1.2 b$ \\
\hline $\mathrm{B}_{5}$ & LDEC & $22.0 \pm 3.5 \mathrm{e}$ & $12.3 \pm 1.0 \mathrm{bc}$ & $32.1 \pm 0.8 \mathrm{e}$ & $19.2 \pm 1.5 b c$ & $39.0 \pm 1.2 \mathrm{~d}$ & $47.3 \pm 3.0 \mathrm{~b}$ \\
\hline MSG & LDEC & $63.0 \pm 2.6 \mathrm{ab}$ & $33.0 \pm 3.7 \mathrm{a}$ & $77.0 \pm 3.4 \mathrm{ab}$ & $53.5 \pm 3.7 \mathrm{a}$ & $92.8 \pm 1.6 \mathrm{a}$ & $104.1 \pm 2.9 \mathrm{a}$ \\
\hline $\mathrm{SH}$ & LDEC & $30.0 \pm 2.3 \mathrm{~cd}$ & $17.7 \pm 1.7 b$ & $40.4 \pm 1.0 \mathrm{~cd}$ & $25.0 \pm 2.6 \mathrm{~b}$ & $66.3 \pm 1.8 b c$ & $75.6 \pm 3.2 \mathrm{ab}$ \\
\hline
\end{tabular}



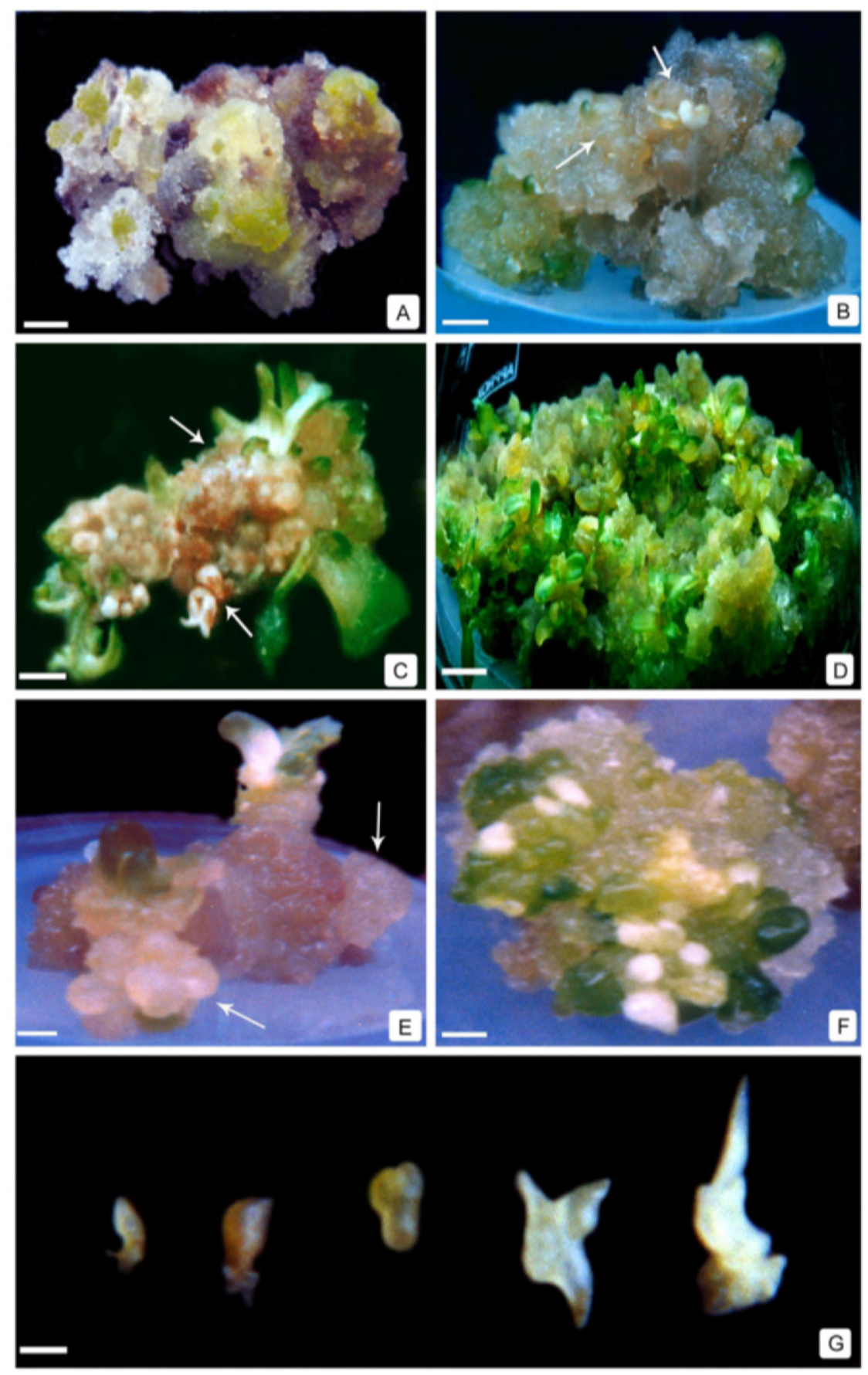

Fig. 1. Cyclic somatic embryogenesis from cotyledon and leaf derived embryogenic callus of safflower: $A$ - Embryogenic callus formed from cotyledon and leaf explants after $70 \mathrm{~d}$ of culture $($ bar $=3.2 \mathrm{~mm}) ; B$ - Primary SE developed from embryogenic callus $($ bar $=3.0 \mathrm{~mm}) ; C, D$ - Proliferation of embryos after $30 \mathrm{~d}$ of culture (bar $=3.5$ and $7.5 \mathrm{~mm}) ; E, F$ - Secondary and cyclic production of SE from embryo culture after $90 \mathrm{~d}$ of culture (bar $=3.7$ and $4.5 \mathrm{~mm}) ; G$ - early globular, heart and torpedo stages of SE $($ bar $=0.85 \mathrm{~mm})$.

MSG after $30 \mathrm{~d}$. However, we also found 33 and $40.4 \%$ of primary embryos from cotyledon and 22 and $30 \%$ from leaf in $\mathrm{B}_{5}$ and $\mathrm{SH}$ media, respectively (Table 2).

Secondary and cyclic somatic embryogenesis: Secondary somatic embryos were formed after $60 \mathrm{~d}$ culture (Fig. 1E). When secondary somatic embryos were maintained under the same culture condition cyclic somatic embryogenesis was obtained by the end of $90 \mathrm{~d}$ (Fig. 1F). Among the three media tested, we noticed $85 \%$ secondary somatic embryogenesis from cotyledon and $77 \%$ from leaf derived embryos after $60 \mathrm{~d}$ of culture in MSG basal medium. However, we have noticed $100 \%$ cyclic production of somatic embryos from cotyledon 
derived secondary embryo culture within $90 \mathrm{~d}$ (Table 2). In this case, MSG media with the addition of myoinositol, casamino acids, L-glutamine, thiamine $\mathrm{HCl}$, pyridoxine $\mathrm{HCl}$, nicotinic acid and L-asparagine showed highest response for the production of primary, secondary and cyclic somatic embryogenesis. The cultures were maintained under continuous irradiance and subcultured in two weeks in the same medium for more than 8 months.

Germination and transplantation of plants: Light white and light yellow globular, heart and torpedo stage embryos turned to green immature cotyledon stages from primary, secondary and cyclic embryonic mass (Fig. 1G) and then placed into germination medium under darkness from which mature cotyledon embryos produced distinct epicotyls with shoot pole and hypocotyl with root poles. In our system, $38.7 \%$ of embryo germination was achived in quarter strength MSG with $1.5 \%$ sucrose, $0.2 \mathrm{mg} \mathrm{dm}^{-3} \mathrm{GA}_{3}, 250 \mathrm{mg} \mathrm{dm}^{-3}$ glutamine, $100 \mathrm{mg} \mathrm{dm}^{-3}$ arginine and $10 \mathrm{mg} \mathrm{dm}^{-3}$ proline at the end of $6^{\text {th }}$ week of culture. However, about $61 \%$ plant conversion rate was the maximum response in filter paper bridges containing $1.0 \%$ sucrose (Table 3, Fig. $2 A$ ). When shoots with root poles and non-root poles were transferred to rooting medium $43.3 \%$ of rooting was observed. However,
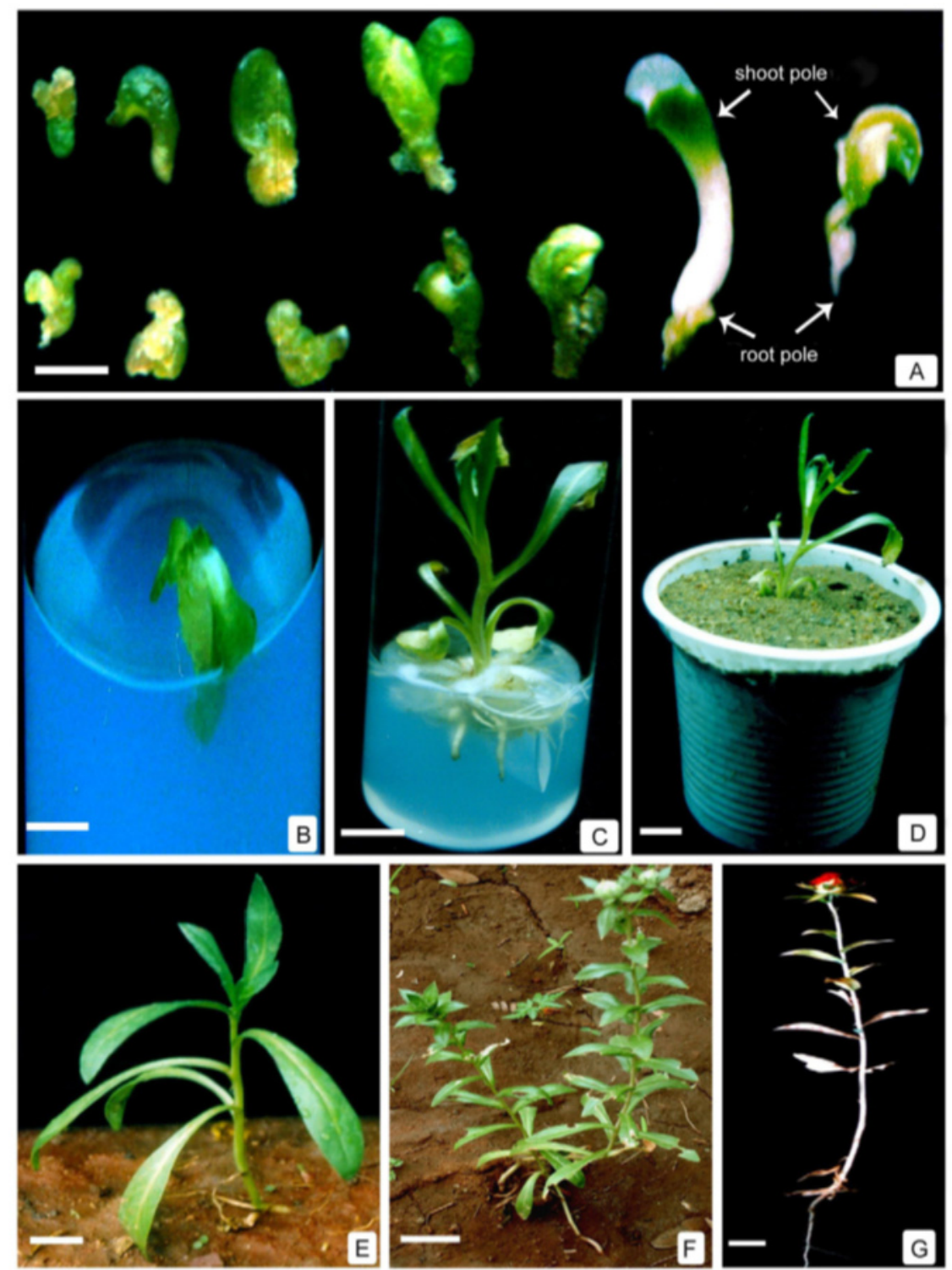

Fig. 2. Developmental stages of plant regeneration of safflower: $A$ - Germination of somatic embryos with shoot and root poles $($ bar $=5.3 \mathrm{~mm}) ; B$ - Germinated embryos showing normal growth with distinct cotyledonary leaves in root induction medium $($ bar $=3.7 \mathrm{~mm}) ; C$ - Adventitious roots formed from the root poles after 30 to $40 \mathrm{~d}$ of culture $($ bar $=5.2 \mathrm{~mm}) . D$ - Regenerated plantlets transferred to plastic cups containing soil mixture $(b a r=8.2 \mathrm{~mm}) ; E, F$ - Plants regenerated through cyclic somatic embryogenesis growing in the field ( $b a r=14$ and $22 \mathrm{~cm}) ; G-E x$ vitro capitula developed with subsequent blooming after 8 weeks $($ bar $=22 \mathrm{~cm})$. 
Table 3. Effect of $\mathrm{GA}_{3}$ on embryo germination and conversion into plantlets. Means of 80 mature embryos \pm SE. Means followed by the same letter within the column are not statistically significant at $P<0.05$.

\begin{tabular}{|c|c|c|c|c|}
\hline $\begin{array}{l}\mathrm{GA}_{3} \\
{\left[\mathrm{mg} \mathrm{dm}^{-3}\right]}\end{array}$ & $\begin{array}{l}\text { Number of embryos germinated at } \\
2^{\text {nd }} \text { week } \quad 4^{\text {th }} \text { week }\end{array}$ & $6^{\text {th }}$ week & $\begin{array}{l}\text { Embryo germination } \\
{[\%]}\end{array}$ & $\begin{array}{l}\text { Plant conversion } \\
{[\%]}\end{array}$ \\
\hline 0.1 & $13.0 \pm 0.4 \mathrm{ab}$ & $26.0 \pm 1.0 \mathrm{ab}$ & $32.5 \pm 0.8 \mathrm{ab}$ & $42.5 \pm 3.3 b$ \\
\hline 0.3 & $17.0 \pm 1.5 \mathrm{a}$ & $31.0 \pm 1.6 \mathrm{a}$ & $38.7 \pm 1.3 \mathrm{a}$ & $61.0 \pm 1.0 \mathrm{a}$ \\
\hline 0.5 & $11.8 \pm 1.6 b c$ & $20.2 \pm 2.2 b$ & $25.2 \pm 1.9 \mathrm{~b}$ & $20.0 \pm 2.6 \mathrm{c}$ \\
\hline 0.7 & $5.1 \pm 1.7 \mathrm{c}$ & $12.7 \pm 2.6 \mathrm{c}$ & $15.8 \pm 3.1 \mathrm{c}$ & $8.2 \pm 1.3 \mathrm{~d}$ \\
\hline 0.9 & $5.5 \pm 2.6 \mathrm{~d}$ & $9.5 \pm 1.3 \mathrm{~d}$ & $11.8 \pm 1.6 \mathrm{~d}$ & $1.5 \pm 0.0 \mathrm{e}$ \\
\hline
\end{tabular}

Table 4. Effect of growth regulators on rooting of germinated embryos. Means of 120 shoots \pm SE. Means followed by the same letter within the column are not statistically significant at $P<0.05$.

\begin{tabular}{llll}
\hline $\begin{array}{l}\text { Growth regulators } \\
{\left[\mathrm{mg} \mathrm{dm}^{-3}\right]}\end{array}$ & $\begin{array}{l}\text { Number of } \\
\text { roots } \\
{[\text { plantlet }}\end{array}$ & $\begin{array}{l}\text { Root length } \\
{[\mathrm{mm}]}\end{array}$ & $\begin{array}{l}\text { Rooting } \\
\text { frequency } \\
{[\%]}\end{array}$ \\
\hline NAA+BA $(2.0+0.1)$ & $2.2 \pm 0.0 \mathrm{ab}$ & $9.2 \pm 1.1 \mathrm{ab}$ & $25.0 \pm 1.3 \mathrm{~b}$ \\
NAA+KN $(1.5+0.3)$ & $2.7 \pm 0.3 \mathrm{ab}$ & $10.5 \pm 1.7 \mathrm{ab}$ & $43.3 \pm 2.6 \mathrm{ab}$ \\
Putrescine (1.5) & $3.5 \pm 0.5 \mathrm{a}$ & $15.6 \pm 1.2 \mathrm{a}$ & $64.1 \pm 2.5 \mathrm{a}$ \\
\hline
\end{tabular}

\section{Discussion}

The embryogenic callus induction is influenced by the genotypes, seedling age of explants, type of callus and different mediua. In earlier studies of safflower, age and position of the explant significantly affected direct somatic embryogenesis in the presence of different carbon source and ethylene inhibitors $\left(\mathrm{AgNO}_{3}, \mathrm{NiCl}_{2}\right.$, DNP) and promoters (ACC, CEPA) in cv. Girna (Mandal et al. 1995, 2001). Mandal and Dutta Gupta (2002) reported the differentiation of multicellular proembryonal complex and development of somatic embryos on NAA and BA supplemented medium. Walia et al. (2007) reported that the endosperms derived calli cultured on adenine sulphate supplemented medium promoted the induction of somatic embryos. We focused on induction of embryogenic callus from cotyledon and leaf explants and the production of primary, secondary and cyclic somatic embryogenesis of safflower cv. NARI-6 and their conversion to plants. In our observations, embryogenic callus induction frequency was significantly increased in TDZ, 2-ip and IBA supplemented medium. The expression of the embryogenic and non-embryogenic callus capacity depended on both the cytokinins and auxin concentrations applied on explants.

We suggested that an interactions between embryogenic callus and different medium strengths (MSG, $\mathrm{B}_{5}$ and $\mathrm{SH}$ ) have an effect on primary somatic embryo initiation but not on callus proliferation. We observed pro-embryogenic cells with white and light green granules, dense cytoplasm, conspicuous nuclei and surprisingly putrescine $\left(1.5 \mathrm{mg} \mathrm{dm}^{-3}\right)$ alone produced $64.1 \%$ rooting (Table 4 , Fig. $2 B, C$ ) in this genotype. After 30 to $40 \mathrm{~d}$ on the rooting medium, the selected regenerated plants were transferred to potting mix (Fig. 2D). Healthy plants were morphologically uniform and grew well to mature plants in ex vitro within a period of $95 \mathrm{~d}$ (Fig. $2 E, F, G$ ). In embryo derived plantlets, shoots and roots grew much slower than normal plants. Over 98 plantlets with well developed roots were successfully transferred to soil from which 52 plants were grown into mature plants in the field condition.

thick cell walls under continuous irradiance. Their further divisions led to globular, heart, torpedo and cotyledonary stages of embryos within $15 \mathrm{~d}$. No vascular connection could be noticed between embryo and embryogenic cell mass. This finding was consistent with earlier studies in Carthamus tinctorius (Mandal and Dutta Gupta 2002). Somatic embryogenesis from embryogenic callus has also been reported in many other plant species (e.g. Nakano et al. 2000, Suzuki and Nakano 2001, Fki et al. 2003, Jameel and Al-Khayri 2004, Ganesh Kumari et al. 2008).

Our study also showed the development of secondary and cyclic somatic embryos from the primary embryogenic culture in the absence of exogenous plant growth regulators in half-strength $\mathrm{B}_{5}, \mathrm{MSG}$ and $\mathrm{SH}$ medium. In this case, PEM were directly generated from the surface of primary embryos. Among the various stages of primary embryos, globular, heart and torpedo stage embryos showed the highest response for induction to secondary and cyclic somatic embryos. Maturing primary, secondary and cyclic somatic embryos possessed distinct bipolar structures with expanded cotyledons. Other plants have also shown secondary and cyclic somatic embryogenesis, e.g., cassava (Sofiari et al. 1997, Ihemere 2003), ceara rubber (Joseph et al. 2000) and black pepper (Ramakrishnan Nair and Dutta Gupta 2006).

In all three different media tested we found an improved production of primary, secondary and cyclic somatic embryos of safflower as compared to previous 
reports (Mandal and Dutta Gupta 2003) when we used PGRs free culture. This kind of induction and maintenance of embryos in PGRs free culture was previously reported in several crops (e.g. Bellarosa et al. 1992, Korlach and Zoglauer 1995, Li et al. 1998a,b, Lelu et al. 1999, Vengadesan et al. 2002, Mori and Nakano 2004, Silveira et al. 2004, Kim et al. 2005, Ramakrishnan Nair and Dutta Gupta 2006).

Upon germination, somatic embryos (8 to $10 \mathrm{~mm}$ ) sprouted cotyledons, hypocotyls and root poles synchronously. $\mathrm{GA}_{3}$ had a positive effect on the elongation of hypocotyls as it has been reported in Cryptomeria japonica (Igasaki et al. 2003) and ginseng (Zhou et al. 2006). Elongated shoots produced efficient rooting on putrescine supplemented medium. Rooting of safflower (cv. NARI-6) plants is not in agreement with earlier reports (Sujatha and Dinesh Kumar 2007).

On the basis of our results we concluded that embryogenic callus maintained in a PGR-free half strength MSG basal medium produced a high frequency of primary, secondary and cyclic somatic embryos. Furthermore, we manage to set the conditions for successful acclimatization of in vitro produced plants to field. Such a system of regeneration of safflower might be highly applicable to many cultivars and allows a more rapid evaluation of the germplasm for the genetic transformation of safflower.

\section{References}

Aitken-Christie, J.: Somatic embryogenesis for large-scale clonal testing and propagation of elite material. - In: AitkenChristie, J. (ed.): Proceedings of the International Conference on Wood, Breeding, Biotechnology and Industrial Expectations. P. 9. Bordeaux 2001.

Becwar, M.R., Wann, S.R., Johnson, M.A., Verhagen, S.A., Feirer, R.P., Nagamani, R.: Development and characterization of in vitro embryogenic system in conifers. - In: Ahuja, M.R. (ed.): Somatic Cell Genetics of Woody Plants. Pp. 1-18. Kluwer Academic Publishers, Dordrecht 1988.

Bellarosa, R., Mo, L.H., Von Arnold, S.: The influence of auxin and cytokinin on proliferation and morphology of somatic embryos of Pices abies (L.) Karst. - Ann. Bot. 70: 199-206, 1992.

Gamborg, O.L., Miller, A., Ojima, K.: Nutrition requirements of suspension cultures of soybean root cells. - Exp. Cell Res. 50: $151-158,1968$.

Ganesh Kumari, K., Ganesan, M., Jayabalan, N.: Somatic organogenesis and plant regeneration in Ricinus communis. - Biol. Plant. 52: 17-25, 2008.

Igasaki, T., Sato, T., Akashi, N., Mohri, T., Maruyama, E., Kinoshita, I., Walter, C., Shinohara, K.: Somatic embryogenesis and plant regeneration from zygotic embryos of Cryptomeria japonica D. Don. - Plant Cell Rep. 22: 239-243, 2003.

Ihemere, U.E.: Somatic embryogenesis and transformation of cassava for enhanced starch production. - PhD Thesis. The Ohio State University, Columbus 2003.

Jain, M.S.: An overview on progress of somatic embryogenesis in forest trees. - In: Altman, A., Ziv, M., Izhar, S. (ed.): Plant Biotechnology and In vitro Biology in the $21^{\text {st }}$ Century. Pp. 57-63. Kluwer Academic Press, Dordrecht 1999.

Jameel, M., A1-Khayri, A.M.: Genotype-dependent in vitro response of date palm (Phanix dactylifera L.) cultivars to silver nitrate. - Sci. Hort. 99: 153-162, 2004.

Joseph, T., Yeoh, H-H., Loh., C-S.: Somatic embryogenesis, plant regeneration and cyanogenesis in Manihot glaziovii Muell. Arg. (ceara rubber). - Plant Cell Rep. 19: 535-538, 2000.

Kim, T.D., Ramesh Anbazhagan, V., Park, J.I.: Somatic embryogenesis in Schisandra chinensis (Turcz) Bail. - In Vitro cell. dev. Biol. Plant 41: 253-257, 2005.

Kohlenbach, H.W.: Comparative somatic embryogenesis. - In: Thorpe, T.A. (ed.): Frontiers of Plant Tissue Culture. Pp.

59-66. International Association for Plant Tissue Culture, Calgary 1978.

Korlach, J., Zoglauer, K.: Developmental patterns during direct somatic embryogenesis in protoplasts culture of european larch (Larix deciduas Mill.). - Plant Cell Rep. 15: 242-247, 1995.

Lelu, M-A., Bastien, C., Drugeault, A., Gouez, M.-L., Klimaszewska, K.: Somatic embryogenesis and plantlet development in Pinus sylvestris and Pinus pinaster on medium with and without growth regulators. - Physiol. Plant. 105: 719-728, 1999.

Li, H.Q., Guo, J.Y., Huang, Y.W., Liang, C.Y., Liu, H.X., Potrykus, J., Puonti Kaerlas, J.: Regeneration of cassava plants via shoot organogenesis. - Plant Cell Rep. 17: 410414, 1998a.

Li, X.Y., Huang, F., Gbur, E., Jr.: Effect of basal medium, growth regulators and Phytagel concentration on initiation of embryogenic culture from immature zygotic embryos of loblolly pine (Pinus taeda L.). - Plant Cell Rep. 17: 298301, 1998b.

Mandal, A.K.A., Chatterji, A.K., Dutta Gupta, S.: Direct somatic embryogenesis and plantlet regeneration from cotyledonary leaves of safflower. - Plant Cell Tissue Organ. Cult. 43: 287-289, 1995.

Mandal, A.K.A., Dutta Gupta, S.: Direct somatic embryogenesis of safflower- a scanning electron microscopic study. - Curr. Sci. 83: 1138-1140, 2002.

Mandal, A.K.A., Dutta Gupta, S.: Somatic embryogenesis of safflower: influence of auxin and ontogeny of somatic embryos. - Plant Cell Tissue Organ. Cult. 72: 27-31, 2003.

Mandal, A.K.A., Dutta Gupta, S., Chatterji, A.K.: Factors affecting somatic embryogenesis from cotyledonary explants of safflower. - Biol. Plant. 44: 503-507, 2001.

Michaux-Ferriere, N., Schwendiman, J.: Initiation sequence patterns for somatic embryos originating cells. - Acta. bot. gallica 140: 603-613, 1993.

Mori, S., Nakano, M.: Somatic embryo induction from leaf-and flower bud-derived calli in several Muscari species and cultivars. - Propag. Ornament. Plant. 4: 58-62, 2004.

Nakano, M., Sakakibara, T., Suzuki, S., Saito, H.: Decrease in the regeneration potential of long-term cell suspension cultures of Lilium formosanum Wallace and its restoration by the auxin transport inhibitor,2,3,5-triiodobenzoic acid. Plant Sci. 158: 129-137, 2000.

Ramakrishnan Nair, R., Dutta Gupta, S.: High-frequency plant 
regeneration through cyclic secondary somatic embryogenesis in black pepper (Piper nigrum L.). - Plant Cell Rep. 24: 699-707, 2006.

Schenk, R.U., Hildebrandt, A.C.: Medium and techniques for induction and growth of monocotyledonous and dicotyledonous plant cell cultures. - Can. J. Bot. 50: 199204, 1972.

Silveira, V., Floh, E.I.S., Handro, W., Guerra, M.P.: Effect of plant growth regulators on the cellular growth and levels of intracellular protein, starch and polyamines in embryogenic suspension cultures of Pinus taeda. - Plant Cell Tissue Organ Cult. 76: 53-60, 2004.

Sofiari, E., Rae Makers, C.J.J.M., Kanju, E., Danso, K., Van Lammeren, A.M., Jacobsen, E., Visser, R.G.F.: Comparison of NAA and 2,4-D induced somatic embryogenesis in cassava. - Plant Cell Tissue Organ Cult. 50: 45-56, 1997.

Sujatha, M., Dinesh Kumar, V.: In vitro bud regeneration of Carthamus tinctorius and wild Carthamus species from leaf expalnts and axillary buds. - Biol. Plant. 51: 782-786, 2007.
Suzuki, S., Nakano, M.: Organogenesis and somatic embryogenesis from callus cultures in Muscari armeniacum Leichtl. ex Bak. - In Vitro cell. dev. Biol. Plant 37: 382-387, 2001.

Vengadesan, G., Ramesh Anbazhagan, V., Prem Anand, R., Ganapathi. A.: Somatic embryogenesis in cell suspension cultures of Acacia sinuate (Lour) Merr. - In Vitro cell dev. Biol. Plant 38: 52-57, 2002.

Von Arnold, S., Eriksson, T.: In vitro studies of adventitious shoot formation in Pinus contorta. - Can. J. Bot. 59: 870874, 1981.

Walia, N., Kaur, A., Babbar, S.B.: Proliferation and differentiation from endosperm of Carthamus tinctorius. Biol. Plant. 51: 749-753, 2007.

Zhou, S., Daniel C., Brown, W.: High efficiency plant production of North American ginseng via somatic embryogenesis from cotyledon explants. - Plant cell. Rep. 25: 166-173, 2006. 